\title{
Animated tectonic reconstruction of the Southern Pacific and alkaline volcanism at its convergent margins since Eocene times
}

\author{
Graeme Eagles $^{\mathrm{a}, *}$, Karsten Gohl $^{\mathrm{b}}$, Robert D. Larter $^{\mathrm{c}}$

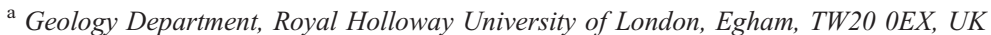 \\ b Alfred Wegener Institute for Polar and Marine Research, Postfach 120161, Bremerhaven D-27515, Germany \\ ${ }^{\mathrm{c}}$ British Antarctic Survey, High Cross, Madingley Road, Cambridge, CB3 OET, UK
}

Received 8 May 2007; received in revised form 11 October 2007; accepted 31 October 2007

Available online 6 November 2007

\begin{abstract}
An animated reconstruction shows South Pacific plate kinematics, in the reference frame of West Antarctica, between 55 Ma and the presentday. The ocean floor in the region formed due to seafloor spreading between the Antarctic, Pacific, Phoenix and Nazca plates (a plate formed by fragmentation of the Farallon plate early in Oligocene times). The Pacific-Antarctic Ridge remained fairly stable throughout this time, migrating relatively northwestwards, by various mechanisms, behind the rapidly-moving Pacific plate. The Nazca and Phoenix plates also moved quickly, but relatively towards the east or southeast, and were subducted in these directions beneath the South American and Antarctic plates. Segments of spreading centres forming at the trailing edges of the Nazca and Phoenix plates periodically collided with these subduction zones, resulting in the total destruction of the Nazca-Phoenix spreading centre and the partial destruction of the Nazca-Antarctica spreading centre (the Chile Ridge) and Antarctic-Phoenix Ridge, which ceased to operate shortly before its northeasternmost three segments could collide with the Antarctic margin. Following collision of segments of the Chile Ridge, parts of the Antarctic plate underwent subduction at the Chile Trench. After these collisions, slab windows should have formed beneath both the South American and Antarctic convergent margins, and the animation shows occurrences of alkaline volcanism that have been, or can newly be, related to them. Further occurrences of alkali basalts, at the margins of the Powell Basin and, more speculatively, James Ross Island, can be related to the formation of a slab window beneath them following the collision of segments of the South America-Antarctica spreading centre in the northwest Weddell Sea.
\end{abstract}

(C) 2007 Elsevier B.V. All rights reserved.

Keywords: Plate kinematics; Subduction; Slab windows; Alkaline volcanism; Antarctica; South America

\section{Introduction}

The Late Cretaceous and early Tertiary plate kinematic history of the Southwest Pacific was complicated and involved independent movements of a small oceanic plate (Stock and Molnar, 1987; Stock et al., 1996; Eagles et al., 2004a), subduction and the consequences of its cessation (Larter et al., 2002), and a major plate-tectonic reorganization around chron C27 ( $61 \mathrm{Ma})$ (Cande et al., 1995).

Further north and east (Fig. 1), and during later times, the situation was somewhat simpler. The Phoenix plate underwent subduction beneath the Antarctic Peninsula at its southeastern

\footnotetext{
* Corresponding author. Tel.: +44 1784 443890; fax: +44 1784471780 .
}

E-mail address: g.eagles@gl.rhul.ac.uk (G. Eagles). boundary, with which segments of the Antarctic-Phoenix ridge periodically collided leading to near-total destruction of the Phoenix plate (Larter and Barker, 1991). During much of Paleogene times, Antarctica underwent extension as the West Antarctic rift system slowly moved East Antarctica apart from West Antarctica, which we assume here included the Antarctic Peninsula (Behrendt et al., 1991; Cande et al., 2000). In addition to this, a complex of oceanic basins developed in the Scotia Sea at the region's eastern extremity, where west-directed subduction of the South American plate resulted in slow eastwards motion of an arc plate, as seen from Antarctica (Eagles et al., 2005). In the northeast of the study area, the Farallon plate moved rapidly eastwards towards a subduction zone at the western margin of South America (Cande and Leslie, 1986). At its southern and western edges, new seafloor material accreted 


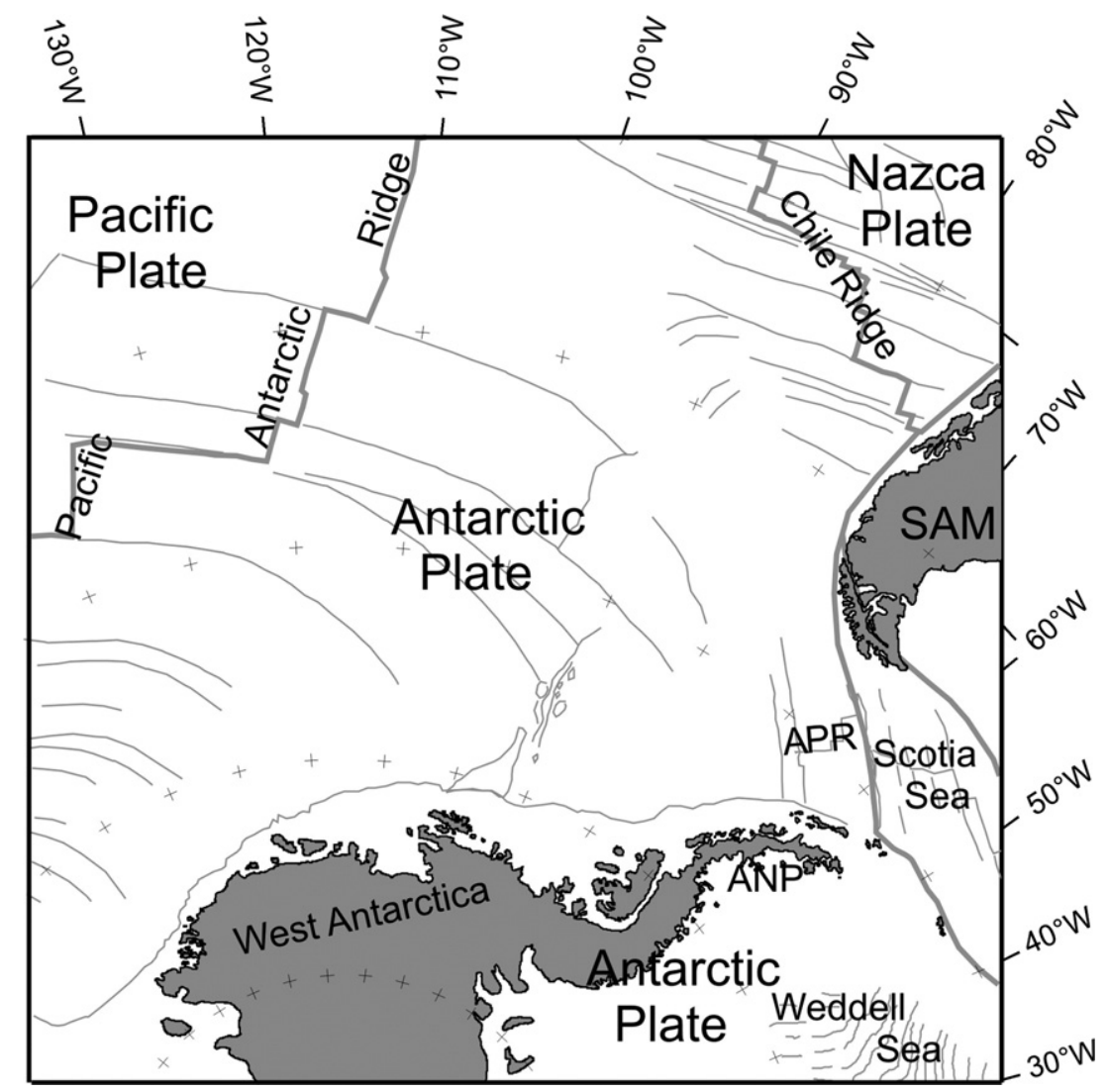

Fig. 1. Prominent lineaments interpreted from gravity anomalies of the southern Pacific, illustrating places referred to in the introduction. ANP: Antarctic Peninsula, APR: Antarctic-Phoenix Ridge, SAM: South America. Present-day plate boundaries are shown as bold grey lines.

to the Farallon plate at its margins with the Pacific, Antarctic and Phoenix plates (Cande et al., 1982). At about $23 \mathrm{Ma}$, the Farallon plate broke up into two smaller plates (Meschede and Barckhausen, 2000) the southern of which, Nazca, continued to subduct at the southern Chile Trench.

From time to time, ridge crests and/or transform faults collided with the subduction zones at the east of the region, changing the identity of the overriding plate and, with it, the rate and azimuth of relative plate motion. As a result, subduction either ceased, or changed in such a way that the subducted slabs momentarily or permanently disappeared from the depths they had previously occupied below the overriding plates, forming so-called slab windows. Worldwide, the formation of slab windows has been related to the presence of alkaline volcanism on the overriding plates in those locations lacking features that are usually taken as independent evidence for extension or mantle plumes, to which such volcanism is otherwise usually attributed (Thorkelson and Taylor, 1989). Because these rocks contain little or no trace of contamination by subduction-related processes, it is thought that they originate when mantle material that had previously been trapped beneath the slab rapidly ascends into the volume vacated by the slab, and undergoes decompression melting.

Here we review together the plate tectonic history of the southern Pacific Ocean and the alkaline volcanism at its convergent margins, using a high resolution animation of plate kinematics illustrated by its oceanic free-air gravity anomalies (McAdoo and Laxon, 1997; Sandwell and Smith, 1997).

\section{Method}

Eagles et al (2004b) describe the creation of a set of grid files showing reconstructed gravity anomalies and the BEDMAP sub-ice topography data set (Lythe et al., 2000) that are used as the bases of colour frames for an animation concentrating on the period 90-45 Ma. In addition to these, for this new animation we have included gridded data showing the onshore topography of South America (Smith and Sandwell, 1996), and gravity data showing the formation of the Powell Basin and motion of the Nazca plate east of the Chile Ridge. To do this we used rotation parameters for Antarctica-Nazca and Powell Basin relative motions taken from Tebbens and Cande (1997) and Eagles and Livermore (2002). Small motions of the Hudson microplate (Eakins, 2002), and the Selkirk, Friday, and other microplates at the margins of the Nazca plate (Tebbens and Cande, 1997; Tebbens et al., 1997) are not depicted as there are no rotations published to describe them, although the incorporated microplates are shown after their extinctions.

As in the earlier study, we show reconstructed plate boundaries and isochron data from Cande et al. (1989) as vector data overlaid on the individual frames. All magnetic anomalies are dated based on the magnetic reversal timescale of 
Cande and Kent (1995). To these vector data, here, we add data showing the occurrence of alkali basalts that have been, or can be, related to the formation and presence of slab windows. In South America, these are shown as either violet-filled point locations or outcrop patterns, and each location persists in the animation for all times between the oldest and youngest published radiometric ages for the occurrence. In Antarctica, where outcrop is limited or alkaline volcanism is known from dredged seafloor samples, we only show point data. The published ages are of varying vintage and reliability, with both $\mathrm{K}$-Ar (particularly in Antarctica) and Ar-Ar dating methods having been used. Where no published dates exist, we have assigned outcrops ages that are the same as the nearest dated occurrences. Where the locations of rocks with published dates are not precisely given, we have assigned the ages to the nearest mapped occurrence of alkaline volcanic rocks that we found in the literature.

\section{Results}

A QuickTime movie shows the parts of the animation covering the period $55 \mathrm{Ma}$ to the present day. The first 10 million years of the animation also appear in Eagles et al's (2004b) contribution. The animation shows a 'traffic light' symbol in its top-right corner that shows red in frames where finite rotations for the gridded part of the reconstruction are interpolated and green where they are based on fits of both magnetic isochrons and fracture zone data. Below, we describe the animation with reference to still frames from important epochs. The figures are annotated in order to enable readers to

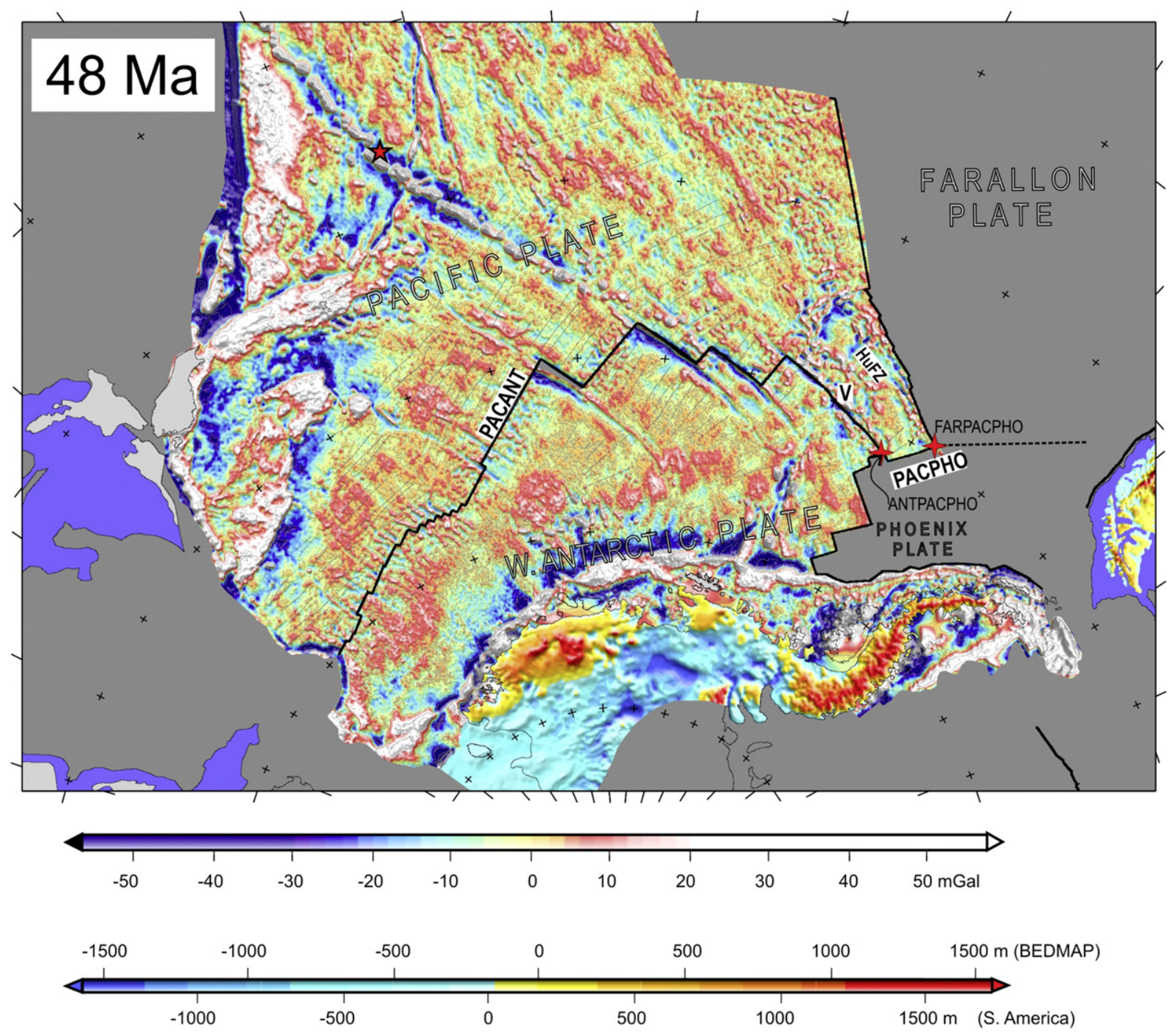

Fig. 2. Reconstruction animation frame for $48 \mathrm{Ma}$, made with respect to a fixed West Antarctica. Red four-point star symbol: triple junctions, in this and following figures labelled with identities of bordering plates: ANT: Antarctica, FAR: Farallon, NAZ: Nazca, PAC: Pacific, PHO: Phoenix. Blue fill: continental shelves (edges defined using satellite-free-air gravity), pale gray fill: simplified present day coastlines. BEDMAP sub-ice topography ( Lythe et al., 2000) and surface topography (Smith and Sandwell, 1997) are shown onshore West Antarctica and South America. No attempt has been made to define the plate boundary between West Antarctica and East Antarctica. Oblique Mercator projection centred on $137.5^{\circ} \mathrm{W}, 65^{\circ} \mathrm{S}$ and with $74^{\circ} \mathrm{W}, 60^{\circ} \mathrm{S}$ on the oblique equator. Graticule interval $10^{\circ}$. HuFZ: Humboldt Fracture Zone, PACANT: Pacific-Antarctic Ridge, PACPHO: Pacific-Phoenix Ridge, V: Fracture Zone "V". 
refer more easily to the text, whereas the equivalent frames in the animation are not.

\subsection{Aftermath of a tectonic reorganisation: 55-46 Ma}

The $48 \mathrm{Ma}$ (chron C20r) reconstruction is shown in Fig. 2. A very long offset transform fault, now visible as the fracture zone "V", has reached its greatest length. The animation shows how this feature grows longer between segments of the PacificAntarctic Ridge, at its northwestern tip, and the PhoenixPacific Ridge, at its southeastern tip. Subsequently, at 47$46 \mathrm{Ma}$, the transform is deactivated when the Pacific-Antarctic ridge propagates through $\sim 15$ m.y. old Pacific plate lithosphere at its western end (Cande et al., 1982; Mammerickx and Sandwell, 1986). This event formed a new Pacific-Antarctic spreading corridor between "V" and the Menard transform fault, changed the Farallon-Pacific-Phoenix triple junction at the southeastern end of the Humboldt Fracture Zone to a FarallonAntarctic-Phoenix one, and created a new Pacific-AntarcticFarallon triple junction at the Menard transform fault. Further south on the Pacific-Antarctic Ridge, a corrugated seafloor pattern can be seen to have just come into existence, which has been related to a decrease in spreading rates occurring during a plate tectonic reorganization at $61 \mathrm{Ma}$ (Eagles et al., 2004b). This event is the latest in a series of events whose consequences are northeastwards lengthening of the Pacific-Antarctic plate boundary.

\subsection{Slab window south of the Tula Fracture Zone: $40 \mathrm{Ma}$}

In the period after $46 \mathrm{Ma}$, lengthening of the PacificAntarctic plate boundary continues by migration of a stable ridge-ridge-ridge triple junction between the Pacific, Antarctic and Farallon plates (Fig. 3). The Antarctic-Farallon-Phoenix triple junction, further south, migrates NE. In the period 35 $25 \mathrm{Ma}$, a large change in relative motions occurs between the Farallon and Antarctica plates. This can be seen in the orientation of fracture zones formed on the Farallon-Antarctic plate boundary, which changes from $\mathrm{N}-\mathrm{S}$ to almost $\mathrm{E}-\mathrm{W}$. This event expresses changes that occurred in the relative motions of the Pacific and Farallon plates in the run-up to the disintegration of the Farallon plate into the Cocos and Nazca plates by the initiation of spreading on the Galapagos Ridge at about $23 \mathrm{Ma}$ (Meschede and Barckhausen, 2000). The Nazca-Antarctic and Pacific-Antarctic plate boundaries propagate rapidly northwards at about $21 \mathrm{Ma}$, in the process capturing an area of the seafloor that is thought to have formed at a ridge crest microplate south of the Valdivia fracture zone (Tebbens and Cande, 1997).

In the northeast, seafloor of the Farallon (and later Nazca) plate subducts beneath South America. As this seafloor no longer exists, it cannot be represented in the animation and appears there as unfilled grey space. Here, we refer to space like this as 'underlap'. Further south, the earliest collisions between segments of the Antarctic-Phoenix Ridge and the subduction

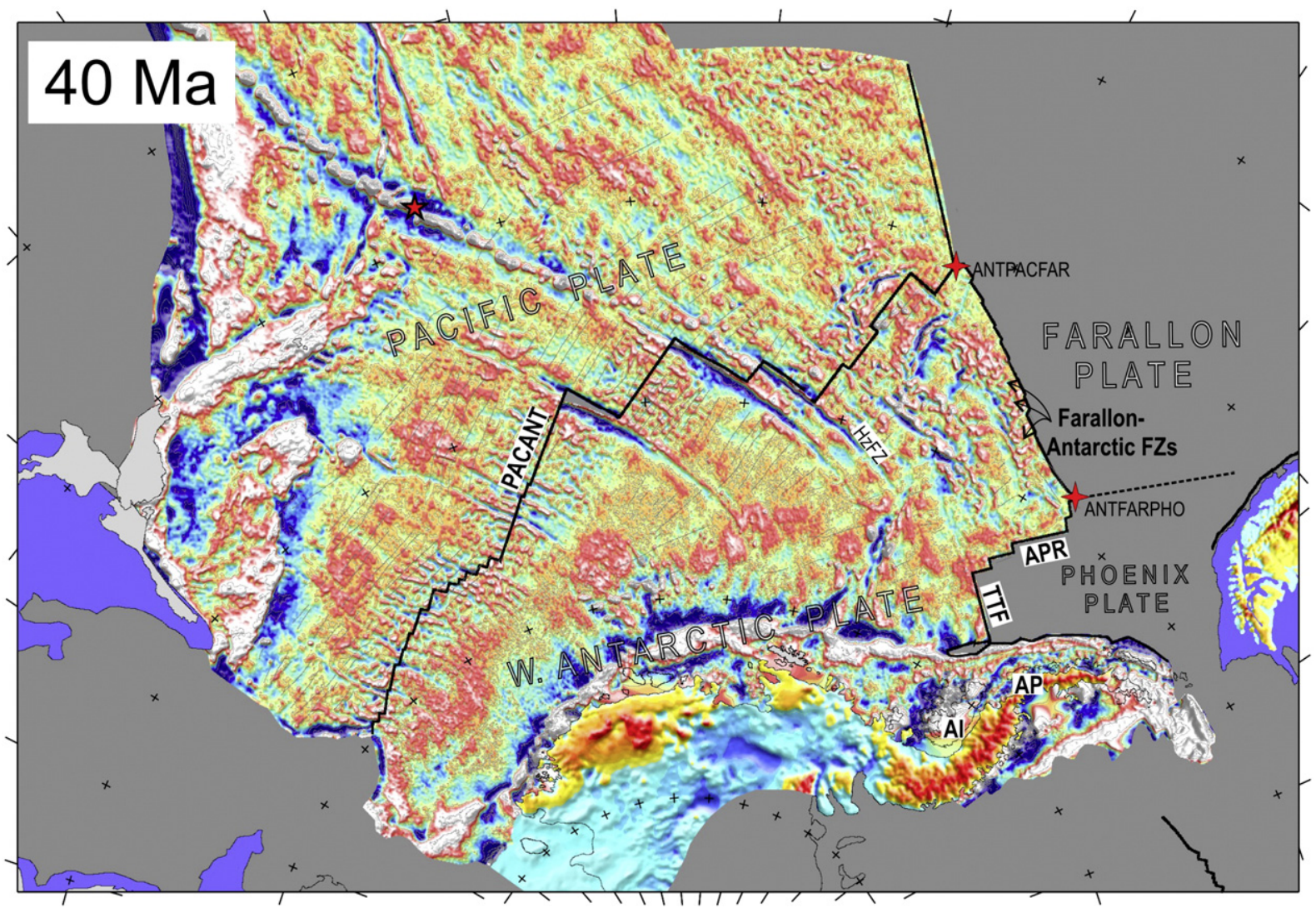

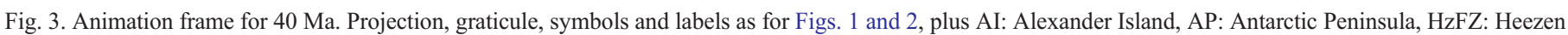
Fracture Zone, TTF: transform fault forming the Tula Fracture Zone. Dotted lines: approximate limits of selected slab windows (see text for details). 
zone at the West Antarctic margin occur starting at around $44 \mathrm{Ma}$, to the south of the transform fault whose action formed the Tula Fracture Zone (McCarron \& Larter, 1998). In this setting, the Antarctic plate was both the trailing plate and the overriding plate, meaning that subduction ought to have stopped after each collision. Consistent with this scenario, calc-alkaline flows and intrusions over and into accretionary prism rocks of the LeMay Group on Alexander Island, all of which can be related to the subduction, cease at about the same time as the ridge crest-trench collisions (Hole, 1988). By halting subduction, each collision should also have contributed to the growth of a slab window beneath the southern parts of the Antarctic Peninsula and Alexander Island. We show the approximate shape of this slab window, assuming subduction at an angle of $45^{\circ}$ and no deformation of the downgoing slab, with a dotted line in Fig. 3 and later figures. The animation, however, shows that alkaline volcanism is not known from above this window until $25 \mathrm{~m}$.y. later, in the form of Mioceneaged lamprophyre dykes on Alexander Island (Smellie et al., 1988).

\subsection{Slab window beneath Powell Basin: 35-20 Ma}

Powell Basin, at the northern tip of the Antarctic Peninsula, opened as a result of the slow eastward movement of the upper, arc, plate to the ancestral South Sandwich-Discovery Trench with respect to Antarctica, as shown by differences in spreading rates between the West Scotia and South American-Antarctic ridges (Eagles et al., 2005; Fig. 4). Barker et al (1982) show that this subduction zone, whose present-day successor is to be found at the South Sandwich Trench, reached at least as far south as the southern edge of the South Orkney Microcontinent, a continental crustal fragment that bears the South Orkney Islands on the basin's eastern flank. A bathymetric ridge about $100 \mathrm{~km}$ southeast of the microcontinent, with highs named Jane Bank and Discovery Bank, is interpreted as the extinct Discovery arc that formed above the subduction zone. Subduction ceased as segments of the South-AmericanAntarctic Ridge in the northern Weddell Sea collided with, or ceased operating just outboard of, the Discovery arc, starting as early as chron C6 (20 Ma) in the SW and most recently at chron C3 (6 Ma) in the northeast (Barker et al., 1982, 1984). The animation shows the active parts of the spreading centre as a black line in the northern Weddell Sea. The cessation of subduction east of the Powell Basin resulted in the basin's extinction by around $20 \mathrm{Ma}$ (Eagles and Livermore, 2002).

These ridge crest-trench collisions would have resulted in the development of a slab window beneath the South Orkney Microcontinent because, as was the case on the western side of the Antarctic Peninsula, the overriding and trailing plates in the subduction system were, by these times, identical: the Antarctic plate. Consistent with the development of such a slab window, dredge samples from the western margin of the South Orkney Microcontinent yielded young (0-4.5 Ma) alkali basalts that

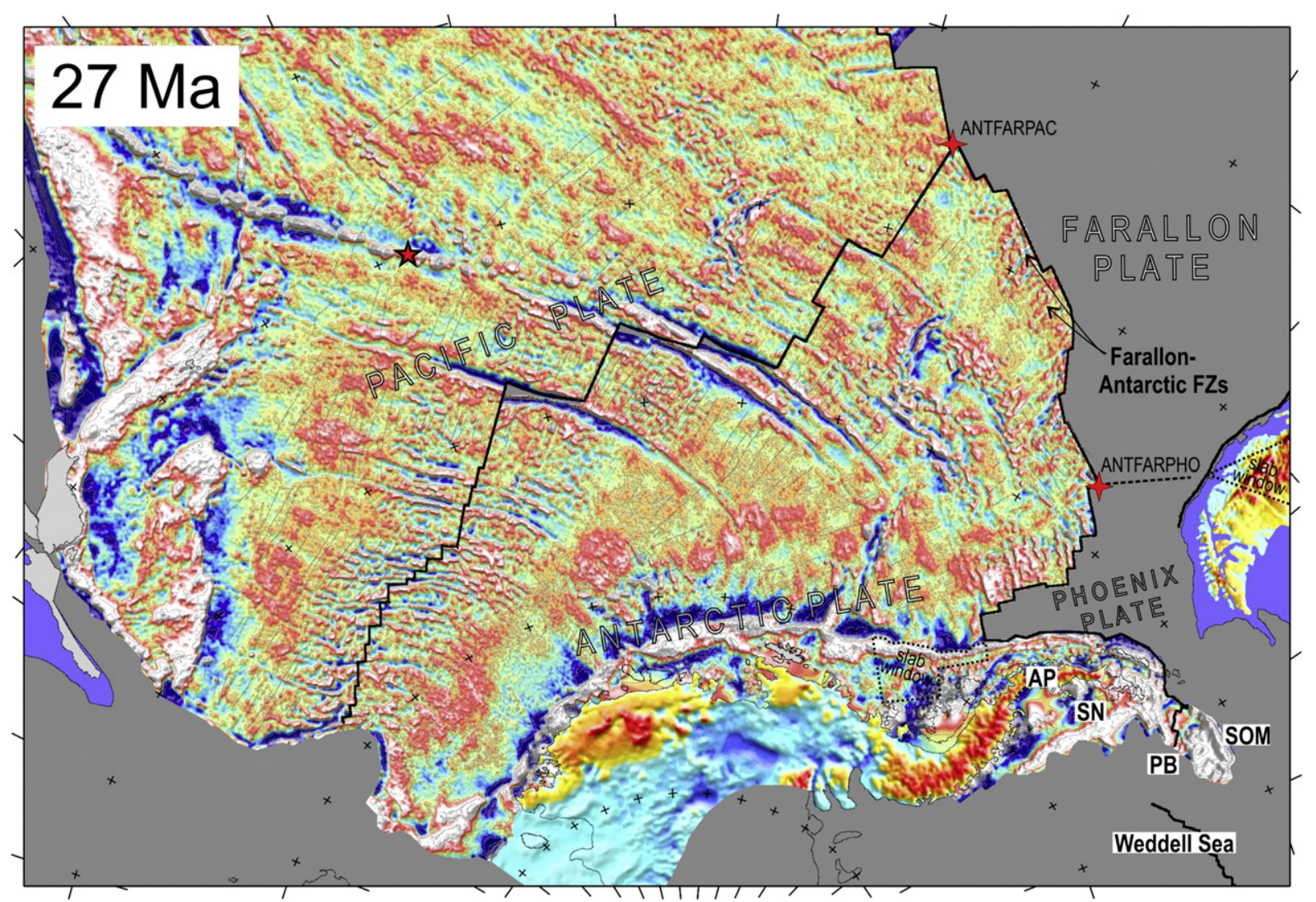

Fig. 4. Animation frame for 27 Ma. Projection, graticule, symbols and labels as for Figs. 2 and 3, plus PB: Powell Basin, SN: Seal Nunataks, SOM: South Orkney Microcontinent. 
Barber et al (1991) found to be geochemically closely comparable to those reported from further south on the Antarctic Peninsula (Smellie et al., 1988). The timing of the start of slab window development here is rather difficult to assess, because the slow spreading rates in the northern Weddell Sea make it difficult to model magnetic profiles running up to the extinct subduction zone with any confidence. If the ages given above are reliable, the time lag between the start of slab window development in the southeast and the eruption of the dredged alkali basalts in Powell Basin is about 15 m.y.

\subsection{Slab windows beneath Cape Horn and north of the Tula Fracture Zone: 20-4 Ma}

Following $20 \mathrm{Ma}$, and the northward propagation of the Pacific-Antarctic and Nazca-Antarctic ridges, the Valdivia transform fault lengthens rapidly by several hundred kilometres between the two northern ridge tips. This process ends at about $13 \mathrm{Ma}$, when the Nazca-Antarctic ridge propagates northwards to the Chile transform fault (beyond the northern edge of the figures and animation), in the process trapping the core of a further ridge-crest microplate, the Friday microplate (Tebbens and Cande, 1997). During the same period, the animation shows how the northeastern tip of the Antarctic-Phoenix ridge very obliquely approaches, and eventually collides with, the southernmost part of the Chile Trench. Before collision, this tip would have been the site of a Nazca-Phoenix-Antarctica triple junction, to the east of which a Nazca-Phoenix spreading centre would have existed and may have been undergoing subduction beneath southernmost South America (e.g. Larter and Barker, 1991). This process should have formed a slab window between the subducting slabs attached to the diverging Nazca and Phoenix plates, to which it is possible to relate the 18.8 18.2 Ma alkali basalts of Packsaddle Island and the Hardy Peninsula, near Cape Horn (Puig et al., 1984). If this is appropriate, the same publication's reported occurrence of $\sim 21$ m.y. old calc-alkaline volcanic rocks also on Hardy Peninsula leads us to conclude that the ridge crest would have been subducted some time between 21 and 19 Ma. Fig. 5, the reconstruction for $20 \mathrm{Ma}$, accordingly shows the NazcaPhoenix spreading centre immediately south of the Chile Trench. With the possible exception of the area lying today immediately west of Elephant Island, all of the seafloor added to the Phoenix plate at this spreading centre seems to have been subducted, meaning there is little chance of being able to independently confirm or refute the proposed presence and action of the slab window caused by its collision.

All this time, and afterwards, accretion continued at the Antarctic-Phoenix Ridge, and the Phoenix plate continued to be subducted beneath the Antarctic Peninsula (Larter and Barker, 1991;Livermore et al., 2000; Eagles, 2003). This situation inevitably led to further ridge crest-trench collisions

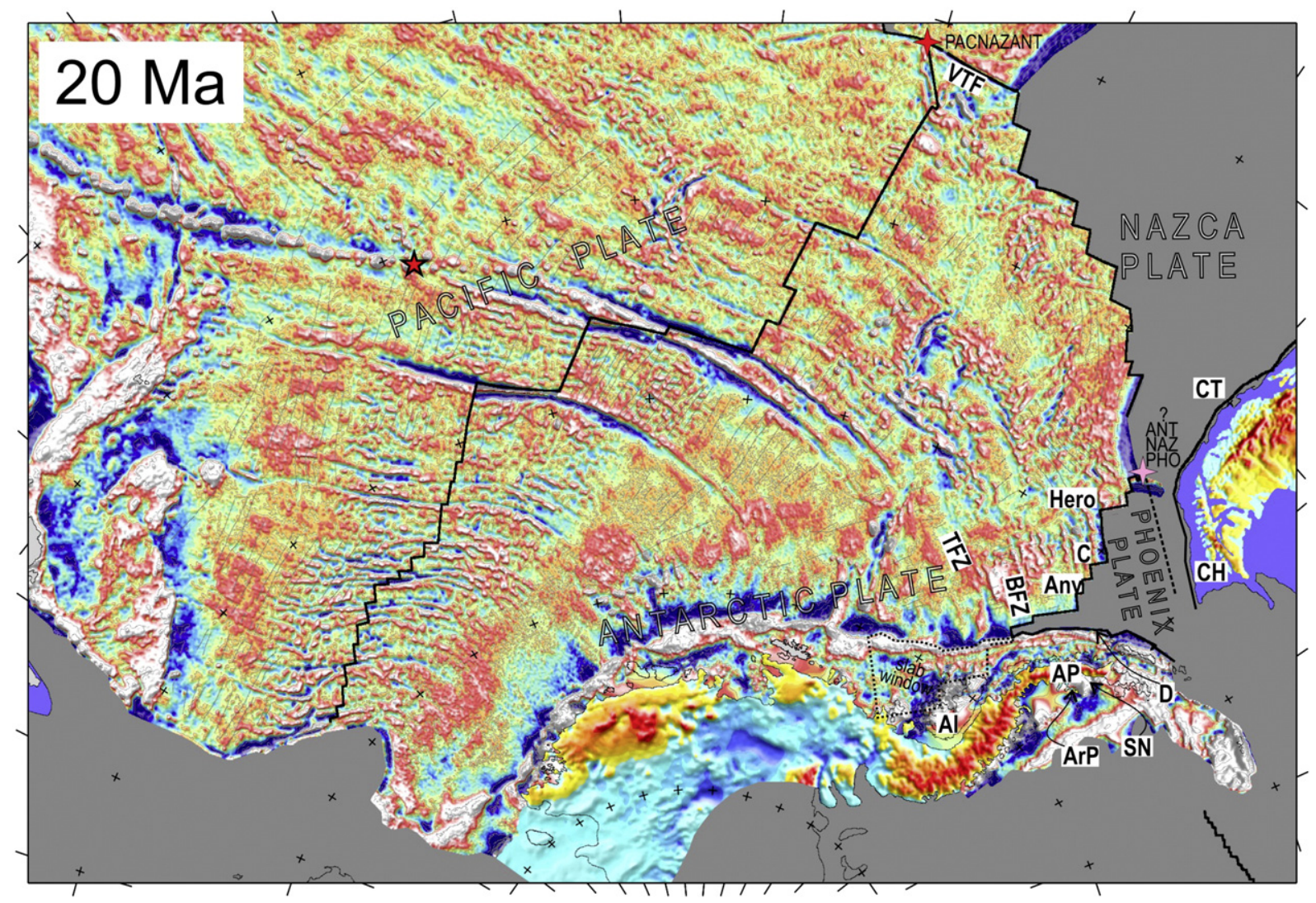

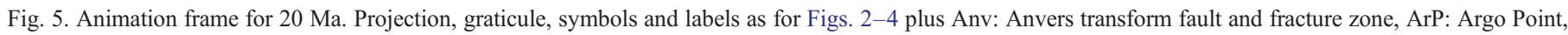

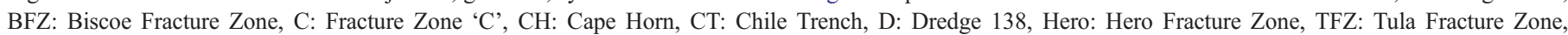
VTF: transform fault forming the Valdivia Fracture Zone. 
like those described southwest of the Tula Fracture Zone, but because of the long-offset on the Tula transform fault the first of these later collisions dates from around $20 \mathrm{Ma}$ (Fig. 5). The animation shows the shortening of this offset as the ridge crest northeast of the Tula Fracture Zone migrates towards the subduction zone in the period $40-20 \mathrm{Ma}$, the ensuing collisions, and the related occurrences of alkali basalts at 'Dredge 138' (recent) Argo Point (1.0 Ma) and Seal Nunataks (4.0 Marecent). Like the Alexander Island occurrences further south, these rocks postdate the opposing ridge crest-trench collisions, in these cases between the Biscoe, Anvers, C, and Hero fracture zones and by 15 m.y., 5.9-5.5 m.y., and 2.4-0 m.y. (Hole and Larter, 1993; Larter et al., 1997).

\subsection{Collisions at the Chile Trench: 15 Ma-present}

The animation illustrates how seafloor of the Farallon/Nazca plates was consumed at the Chile Trench, in the form of the narrowing of the underlap between the oldest surviving Nazca seafloor and the collisional margin of South America. Following collisions of segments of the Nazca-Antarctic plate boundary (the Chile Ridge) with the trench, which started in mid Miocene times in the south and are ongoing at the Chile Triple Junction today, the Antarctic plate followed the Nazca plate into subduction. Because of this subduction of Antarctic seafloor, we can only show the southern segments of the Chile Ridge as a dotted line crossing the underlap in the animation during the period 20-1 Ma (Fig. 6). The animation shows how segments of this ridge crest collided periodically with the Chile Trench and entered the subduction zone, starting in the south before $15 \mathrm{Ma}$.

Following these collisions, a slab window formed beneath Patagonia due to the differential rates of subduction; the Antarctica plate converges with South America more slowly than the Nazca plate does, and presumably sinks more slowly into the asthenosphere too. That a slab window did form is consistent with the widespread Miocene alkaline volcanic rocks (Ramos and Kay, 1992; D'Orazio et al., 2000; 2001; 2004; Gorring et al., 1997). The slab window is mapped approximately in Fig. 6, using the same assumptions as for the slab window beneath the Antarctic Peninsula. The animation shows that, unlike most occurrences on the Antarctic Peninsula, the Patagonian alkaline volcanic rocks are much more closely related in time with the presence of the slab window. The differences in delay times might most simply be related to the erosion of older alkali basalt occurrences by ice sheets on the Antarctic Peninsula and/or their burial beneath ice and younger flows in long lived complexes. One observation consistent with these possibilities is that where ridge-crest-trench collisions have occurred more recently off the northern Antarctic Peninsula, the oldest known alkaline volcanism tends to occur after a smaller time lag. Alternatively, Hole et al (1995) suggested the time lags observed for the Antarctic Peninsula alkaline volcanism may be meaningful in terms of the geometry

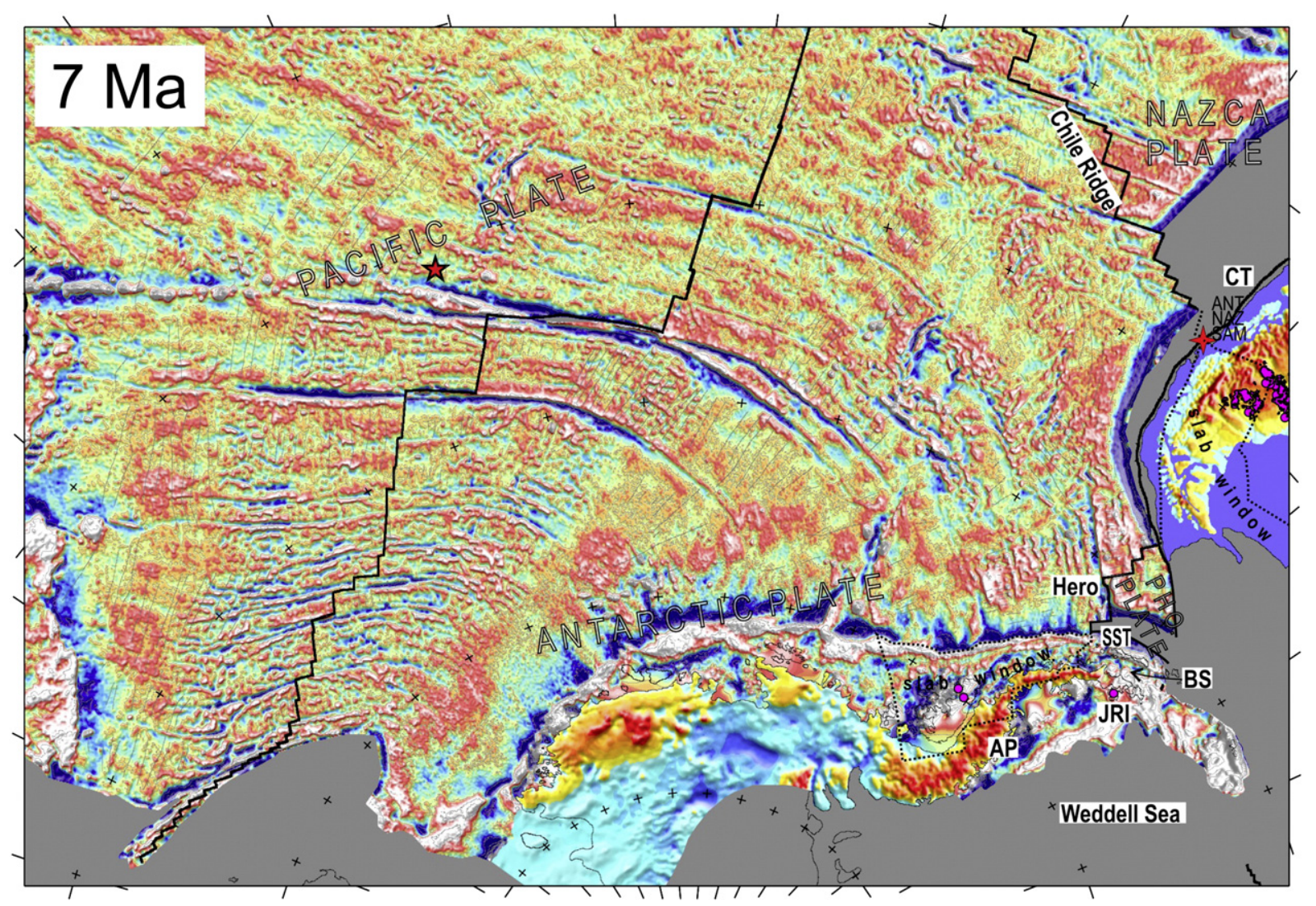

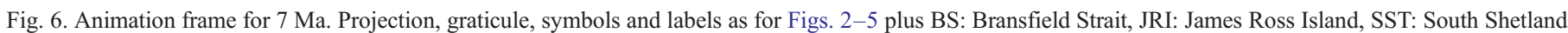
Trench. Violet disks and shapes: alkaline volcanism localities. 
of the slab window, with more delayed occurrences occurring over the 'subducted transform' edges of the window. Similar relationships have not, however, been reported in Patagonia.

The animation shows occurrences of Miocene alkaline volcanic rocks in southern Patagonia that pre-date the collisions that initiated slab-window opening, or that occur north of the Chile Triple Junction. Because they could not have formed by upwelling through the post-15 Ma Nazca-Antarctica slab window, these occurrences have been related to supra-slab processes (as summarised by D'Orazio et al., 2004). Further alkali basalt complexes, dating back through Oligocene and Eocene times, are widespread north of the present-day Chile Triple Junction as far as $43^{\circ} \mathrm{S}$, and have been related to a slab window formed between the Farallon and Phoenix slabs as the spreading centre between these plates was subducted off Chile (Ramos and Kay, 1992). This collision is poorly known but, by assuming the spreading centre had no large offsets, Cande and Leslie (1986) suggested it migrated rapidly southwards during Eocene times from $43^{\circ} \mathrm{S}$ to Tierra del Fuego, leaving subduction of the Farallon Plate in its wake. Earlier, we showed that a Nazca-Phoenix ridge-crest-trench collision probably occurred off Cape Horn at around $18 \mathrm{Ma}$, suggesting the Farallon/NazcaPhoenix slab window may have developed more widely and lingered beneath Patagonia longer than previously thought, perhaps making it possible to relate some of the proposed 'supraslab' volcanics to a slab window after all.

\section{Discussion: James Ross Island volcanism and slab windows}

At James Ross Island, alkaline volcanism dating from 7.1 Ma to recent times cannot be related to a ridge crest-trench collision at the western margin of the Antarctic Peninsula, as the Antarctic-Phoenix Ridge northeast of the Hero Fracture Zone never reached the South Shetland Trench (Hole et al., 1995). Because of this, those authors suggested that the James Ross Island Volcanic Group is not slab-window related, but instead the result of decompression melting that occurred when slab rollback induced asthenospheric flow into the region below a pre-existing rift basin. Flow may instead have occurred around the edges of the very narrow late-stage Phoenix slab, as Barker and Austin (1998) suggested played a role in the initiation of trench rollback and back-arc extension in Bransfield Strait.

Alternatively, we suggest that the James Ross Island Volcanic Group could be related to the slab window that formed below Powell Basin after ridge-crest-trench collisions in the northern Weddell Sea. This possibility is hard to assess with any rigour due to the sparsity of geophysical data in the northwestern corner of the Weddell Sea, which makes it difficult to pinpoint the western limit of the extinct subduction zone there, and the lack of information relating to the relative positions of the South American and Phoenix slabs in the asthenosphere below the northeastern Antarctic Peninsula (Robertson Maurice et al., 2003). Nonetheless, evidence for a Maastrichtian-Paleogene calc-alkaline volcanic source nearby to the east of James Ross Island (Lomas and Dingle, 1999) supports the idea that westdirected subduction may indeed have introduced a slab into the asthenosphere very close by, making the later opening of a slab window a possibility that should be taken into account for the James Ross Island Volcanic Group.

\section{Summary}

An animated reconstruction shows the post-Eocene plate tectonic development of the southern Pacific Ocean.

- The animation depicts known ridge crest trench collision events at the margins of South America and the Antarctic Peninsula along with known occurrences of alkali volcanism, and is consistent with published studies that connect these observations with the concept of decompression melting in slab windows.

- The occurrence of 18 m.y. old alkali volcanism near Cape Horn prompts us to suggest that a slab window formed there following collision of part of a Nazca-Phoenix spreading centre with the southernmost Chile Trench, although no seafloor record of this event remains.

- The animation prompts us to relate the formation of a slab window beneath the northeastern Antarctic Peninsula, as suggested by seafloor data, to alkali volcanism in the Powell and, more speculatively, James Ross basins.

\section{Acknowledgements}

This project was funded by the German Research Foundation (DFG) through the grants GO 724/2-1 and GO 724/2-2. The figures and animation were produced making much use of the Generic Mapping Tools (Wessell and Smith, 1998).

\section{Appendix A. Supplementary data}

Supplementary data associated with this article can be found, in the online version, at doi:10.1016/j.tecto.2007.10.005.

\section{References}

Barber, P.L., Barker, P.F., Pankhurst, R.J., 1991. Dredged rocks from Powell Basin and the South Orkney Microcontinent. In: Thomson, M.R.A., Crame, J.A., Thomson, J.W. (Eds.), Geological Evolution of Antarctica. Proceedings V International Conference, Antarctic Earth Sciences. Cambridge University Press, Cambridge, UK, pp. 361-367.

Barker, P.F., Hill, I.A., Weaver, S.D., Pankhurst, R.J., 1982. The origin of the eastern South Scotia Ridge as an intraoceanic island arc. In: Craddock, C. (Ed.), Antarctic Geoscience. U. Wisconsin Press, Madison, pp. 203-211.

Barker, P.F., Barber, P.L., King, E.C., 1984. An early Miocene ridge cresttrench collision on the South Scotia Ridge near $36^{\circ} \mathrm{W}$. Tectonophysics 102 , 315-332.

Barker, D.H.N., Austin, J.A., 1998. Rift propagation, detachment faulting, and associated magmatism in Bransfield Strait, Antarctic Peninsula. J. Geophys. Res. 103, 24017-24043.

Behrendt, J.C., LeMasurier, W.E., Cooper, A.K., Tessensohn, F., Trehu, A., Damaske, D., 1991. Geophysical studies of the West Antarctic Rift System. Tectonics 15, 1257-1273.

Cande, S.C., Herron, E.M., Hall, B.R., 1982. The early Cenozoic tectonic history of the southeast Pacific. Earth Planet. Sci. Lett. 57, 63-74.

Cande, S.C., Leslie, R.B., 1986. Late Cenozoic tectonics of the southern Chile Trench. J. Geophys. Res. 91, 471-496. 
Cande, S.C., LaBrecque, J.L., Larson, R.L., Pitman III, W.C., Golovchenko, X. Haxby, W.F., 1989. Magnetic lineations of the worlds ocean basins (map no. 131). Am. Assoc. Pet. Geol. Tulsa, OK, USA.

Cande, S.C., Stock, J.M., Müller, R.D., Ishihara, T., 2000. Cenozoic motion between East and West Antarctica. Nature 404, 145-150.

Cande, S.C., Kent, D.V., 1995. Revised calibration of the geomagnetic polarity time scale for the late Cretaceous and Cenozoic. J. Geophys. Res. 100, 6093-6096.

Cande, S.C., Raymond, C.A., Stock, J., Haxby, W.F., 1995. Geophysics of the Pitman Fracture Zone and Pacific-Antarctic plate motions during the Cenozoic. Science 270, 947-953.

D’Orazio, M., Agostini, S., Mazzarini, F., Innocenti, F., Manetti, P., Haller, M.J., Lahsen, A., 2000. The Pali Aike volcanic field, Patagonia: slabwindow magmatism near the southern tip of South America. Tectonophysics 321, 407-427.

D’Orazio, M., Agostini, S., Innocenti, F., Haller, M.J., Manetti, P., Mazzarini, F., 2001. Slab window-related magmatism from southernmost South America: the late Miocene mafic volcanics from the Estancia Glencross area $\left(\sim 52^{\circ} \mathrm{S}\right.$, Argentina-Chile). Lithos 57, 67-89.

D’Orazio, M., Innocenti, F., Manetti, P., Haller, M.J., 2004. Cenozoic back-arc magmatism of the southern extra-Andean Patagonia ( $44^{\circ} 30^{\prime} \mathrm{S}-52^{\circ} \mathrm{S}$ ): A review of geochemical data and geodynamic interpretations. Revista de la Asociación Geológica Argentina 59, 525-538.

Eagles, G., 2003. Tectonic evolution of the Antarctic-Phoenix plate system since 15 Ma. Earth Planet. Sci. Lett. 217, 97-109.

Eagles, G., Livermore, R.A., 2002. Opening history of Powell Basin, Antarctic Peninsula. Marine Geology 185, 195-205.

Eagles, G., Gohl, K., Larter, R.D., 2004a. Life of the Bellingshausen plate. Geophys. Res. Lett. 31, L07603. doi:10.1029/2003GL019127.

Eagles, G., Gohl, K., Larter, R.D., 2004b. High resolution animated tectonic reconstruction of the South Pacific and West Antarctic margin. Geochem., Geophys., Geosystems 5, Q07002. doi:10.1029/2003GC000657.

Eagles, G., Livermore, R.A., Fairhead, J.D., Morris, P., 2005. Tectonic evolution of the west Scotia Sea. J. Geophys. Res. 110, B02401. doi:10.1029/ JB2004003154.

Eakins, B.W., Structure and Development of Oceanic Rifted Margins, PhD Thesis, University of California San Diego, 2002.

Gorring, M.L., Kay, S.M., Zeitler, P.K., Ramos, V.A., Rubiolo, D., Fernandez, M.I., Panza, J.L., 1997. Neogene Patagonian plateau lavas: continental magmas associated with ridge collision at the Chile Triple Junction. Tectonics $16,1-17$.

Hole, M., 1988. Post subduction alkaline volcanism along the Antarctic Peninsula. J. Geol. Soc. Lond. 145, 985-998.

Hole, M., Larter, R.D., 1993. Trench-proximal volcanism following ridgecrest-trench collision along the Antarctic Peninsula. Tectonics 12, 897-910.

Hole, M.J., Saunders, A.D., Rogers, G., Sykes, M.A., 1995. The relationship between alkaline magmatism, lithospheric extension and slab window formation along continental destructive plate boundaries. In: Smellie, J.L. (Ed.), Volcanism Associated with Extension at Consuming Plate Margins. Geol. Soc. Lond. Spec. Pub., 81, pp. 265-285.

Larter, R.D., Barker, P.F., 1991. Effects of ridge-crest-trench interaction on Antarctic-Phoenix spreading: forces on a young subducting plate. J. Geophys. Res. 96, 19583-19607.

Larter, R.D., Cunningham, A.P., Barker, P.F., Gohl, K., Nitsche, F.O., 2002. Tectonic evolution of the Pacific margin of Antarctica 1. Late Cretaceous tectonic reconstructions. J. Geophys. Res. 107 (B12), 2345. doi:10.1029/ 2000JB000052.
Larter, R.D., Rebesco, M., Vanneste, L.E., Gambôa, L.A.P., Barker, P.F., 1997. Cenozoic tectonic, sedimentary and glacial history of the continental shelf west of Graham Land, Antarctic Peninsula. In: Barker, P.F., Cooper, A.K. (Eds.), Geology and Seismic Stratigraphy of the Antarctic Margin, 2. AGU Antarct. Res. Ser., vol. 71, pp. 1-27.

Livermore, R.A., Balanyá, J.C., Maldonado, A., Martínez, J.M., RodríguezFernández, J., Sanz de Galdeano, C., Galindo-Zaldívar, J., Jabaloy, A., Barnolas, A., Somoza, L., Hernández-Molina, J., Suriňach, E., Viseras, C., 2000. Autopsy on a dead spreading center: the Phoenix Ridge, Drake Passage, Antarctica. Geology 28, 607-610.

Lomas, S.A., Dingle, R.V., 1999. Possible evidence for Late Cretaceous off-axis volcanism in the outer James Ross Basin. Antarct. Sci. 11, 332-337.

Lythe, M.B., Vaughan, D.G., and the BEDMAP Consortium, 2000. BEDMAPbed topography of the Antarctic. 1:10,000,000 scale map. BAS, 2000. (Misc) 9 . Cambridge, British Antarctic Survey,

Mammerickx, J., Sandwell, D., 1986. Rifting of old oceanic lithosphere. J. Geophys. Res. 91, 1975-1988.

McAdoo, D.C., Laxon, S., 1997. Antarctic tectonics: constraints from an ERS-1 satellite marine gravity field. Science 276, 556-560.

McCarron, J.J., Larter, R.D., 1998. Late Cretaceous to early Tertiary subduction history of the Antarctic Peninsula. J. Geol. Soc. London 155, 255-268.

Meschede, M., Barckhausen, U., 2000. In: Silver, E.A., Kimura, G., Shipley, T.H. (Eds.), Plate tectonic evolution of the Cocos-Nazca spreading center. Proc. ODP, Sci. Results, 170. Ocean Drilling Program, College Station, TX. [Online]. Available from World Wide Web:http://www-odp.tamu.edu/publications/ 170_SR/chap_07/chap_07.htm.

Puig, A., Herve, M., Suarez, M., Saunders, A.D., 1984. Calc-alkaline and alkaline Miocene and calc-alkaline Recent volcanism in the southernmost Patagonian cordillera, Chile. J. Volcanol. Geotherm. Res. 21, 149-163.

Ramos, V.A., Kay, S.M., 1992. Southern Patagonian plateau basalts and deformation: backarc testimony of ridge collisions. Tectonophysics 205, 261-282.

Robertson Maurice, S.D., Wiens, D.A., Shore, P.J., Vera, E., Dorman, L.M., 2003. Seismicity and tectonics of the South Shetland Islands and Bransfield Strait from a regional broadband seismograph deployment. J. Geophys. Res. 108 (B10), 2461. doi:10.1029/2003JB002416.

Sandwell, D.T., Smith, W.H.F., 1997. Marine gravity anomaly from Geosat and ERS 1 satellite altimetry. J. Geophys. Res. 102, 10039-10054.

Smellie, J.L., Pankhurst, R.J., Hole, M.J., Thomson, J.W., 1988. Age, distribution and eruptive conditions of Late Cenozoic alkaline volcanism in the Antarctic Peninsula and Ellsworth Land: review. Br. Antarct. Surv. Bull. 80 .

Smith, W.H.F., Sandwell, D.T., 1997. Global seafloor topography from satellite altimetry and ship depth soundings. Science $277,1956-1962$.

Stock, J.M., Molnar, P., 1987. Revised early Tertiary history of plate motions in the Southwest Pacific. Nature 325, 495-499.

Stock, J.M., Cande, S.C., Raymond, C.A., 1996. Updated history of the Bellingshausen Plate, Eos Trans. AGU, 77, Fall Meet. Suppl., F647.

Tebbens, S.F., Cande, S.C., 1997. Southeast Pacific tectonic evolution from early Oligocene to Present. J. Geophys. Res. 102, 12061-12084.

Tebbens, S.F., Cande, S.C., Kovacs, L., Parra, J.C., LaBrecque, J.L., Vergara, H., 1997. The Chile Ridge: a tectonic framework. J. Geophys. Res. 102, 12035-12059.

Thorkelson, D.J., Taylor, R.P., 1989. Cordilleran slab windows. Geology 17, 833-836.

Wessel, P., Smith, W.H.F., 1998. New, improved version of Generic Mapping Tools released. EOS 79, 579 